\title{
Iron Deficiency, Ferritin and Total Iron Binding Capacity Among Bangladeshi Children: Urban and Rural Settings
}

\section{Swapan Kumar Chowdhury ${ }^{1 *}$, Shafi Ahmed², Palash Chandra Banik $^{3}$, Poly Immaculata Costa ${ }^{4}$, Rabeya Yasmin ${ }^{5}$, MH Faruquee ${ }^{5}$, SK Akhtar Ahmad $^{6}$, AFM Salim ${ }^{7}$}

${ }^{1}$ PhD Fellow, Bangladesh University of Professionals, Bangladesh

${ }^{2}$ Associate Professor, Department of Pediatrics, Khwaja Yunus Ali Medical College and Hospital, Sirajganj, Bangladesh

${ }^{3}$ Assistant Professor, Department of Non-Communicable Diseases, Bangladesh University of Health Sciences

${ }^{4}$ Assistant Professor, Grameen Caledonian College of Nursing, Dhaka, Bangladesh

${ }^{5}$ Assistant Professor, Department of Occupational and Environmental Health, Bangladesh University of Health Sciences, Bangladesh

${ }^{6}$ Professor, Department of Occupational and Environmental Health, Bangladesh University of Health Sciences, Bangladesh

${ }^{7}$ Ex-Professor, Institute of Child Health and Shishu Swasthya Foundation Hospital, Mirpur, Dhaka, Bangladesh

*Corresponding Author: Swapan Kumar Chowdhury, PhD Fellow, Bangladesh University of Professionals, Dhaka, Bangladesh

DOI: $10.31080 /$ ASNH.2020.04.0628
Received: January 08, 2020

Published: January 29, 2020

(C) All rights are reserved by Swapan Kumar Chowdhury., et al.

\begin{abstract}
In iron deficiency (ID) body tries to compensate by producing more transferrin to increase iron transport and thus transferrin and TIBC increase. This cross-sectional study was conducted among 274 children from two primary schools; one urban (Dhaka city) and one rural (Gazipur district). By sex and area of residence ratio was equal with mean age $8.86 \pm 2.035$ years. Phlebotomist collected venous blood with all aseptic precaution. Estimation of serum Hemoglobin, serum Iron, serum and Total Iron Binding Capacity (TIBC) were done in a reference laboratory. Serum iron level was found below $50 \mu \mathrm{g} / \mathrm{dl}$ among all the subjects. Only mean hemoglobin was found statistically significant difference between the age group of within and above 10 years of subjects, hemoglobin and Ferritin were found significantly more among male over female subjects and hemoglobin, iron, and Ferritin among rural subjects over urban subjects $(p<0.05)$. Higher serum Ferritin was found associated with higher serum iron and serum TIBC was found negatively correspond with serum iron $(\mathrm{p}<0.05)$. Plant-based foods containing non-heme iron may also suggested for Bangladeshi children.
\end{abstract}

Keywords: Serum Vitamin D; Children; Urban and Rural Settings; Bangladesh

\section{Introduction}

Iron deficiency anemia is considered as one of the serious public health problems in Bangladesh. Nutritional anemia is an acquired problem due to consumption of inadequate diet and also of insufficient bio-available essential nutrients to meet the need for hemoglobin and red blood cell synthesis. Ferritin is an intracellular iron storage protein and a marker of iron stores. Iron deficiency can be detected seeing the low ferritin values. Elevated levels of ferritin frequently indicate iron overload caused by damaged hepatocytes; inflammatory disorders; liver disease; alcohol excess; or malignancy [1].
Plasma transferrin, the most important physiological source of iron, is a glycoprotein synthesized in the liver and together with ferritin binds essentially all circulating plasma iron [2]. Under physiologic conditions, this chelation renders iron soluble, prevents iron-mediated free-radical toxicity, and facilitates iron transport into cells. The total iron binding capacity (TIBC) of plasma is depends on the totality of all iron binding sites on transferrin. Transferrin binds tightly to the cell receptor and is drawn into the cell to release its iron. Once in the cytoplasm, iron is delivered to various intracellular locations including mitochondria for heme biosynthesis and to ferritin for storage. The receptor releases the "empty" transferrin to the cell exterior to continue gathering iron. 
Metabolically inactive iron is stored in ferritin and hemosiderin, and is in equilibrium with exchangeable iron bound to carrier molecules. TIBC quantitatively measures serum transferrin and can be useful in diagnosis of iron deficiency anemia, iron overload and chronic inflammatory disorders [3].

Increased levels of TIBC suggest that total iron body stores are low, increased concentrations may be a sign of iron deficiency anemia [4]. Decreased levels of TIBC may indicate anemia of chronic disease such as hemolytic anemia, hemochromatosis, chronic liver disease, hypoproteinemia, malnutrition, pernicious anemia, and sickle cell anemia [5]. Therefore, iron deficiency can be defined as a low serum iron and ferritin with an raised TIBC whereas, a low serum ferritin is virtually diagnostic of iron deficiency alone, on the other hand, a normal serum ferritin can be reported in patients with co-existent diseases (Hepatitis, anaemia of chronic disorders) in spite of deficient in iron [6].

If iron deficiency continues, all of the stored iron is used and the body tries to compensate by producing more transferrin to increase iron transport. The serum iron level continues to decrease and transferrin and TIBC increase [7].

Use of iron status as biomarker in diagnosing anemia may make confusion as this is sometimes influenced by inflammation [8]. This cross-sectional study is an attempt to explore the association of Ferritin and TIBC with iron deficiency among school going anemic children in Bangladesh.

\section{Materials and Methods}

This was a community based cross-sectional study which was conducted among 274 primary school children during March 2018 to February 2019. Two primary schools were selected purposively (one from Dhaka city and one from Gazipur district). After taking assent from guardians all required data were collected. At the time of enrollment, trained research assistants administered a pretested socio-demographic questionnaire of each participating subject. Socio-demographic information including age, household size, education of parents or caregiver, income, employment of the head of the households and housing condition were recorded. Venous blood was collected in the morning taking after a $4-6$ hour overnight fast by trained phlebotomist. Samples were taken in the red-top tube for serum separator. Then the tubes were kept in cold box and sent to the reference laboratory within 4-h. For Hemoglobin estimation, blood was diluted in a solution containing potassium cyanide and potassium ferricyanide. The absorbance of the solution was then measured in a spectrophotometer at a wavelength of $540 \mathrm{~nm}$. For serum Iron analysis, the sample volume for individual test, $25 \mu \mathrm{l}$ was added to $210 \mu \mathrm{l}$ of reagent. Borosilicate glass containers were used to store samples. The Serum Iron was tested through using Beckman Synchron LX20, serum ferritin was analyzed using immunoradiometric procedure (Ramco Laborato- ries, Stafford, TX, USA) and Total iron binding capacity (TIBC) was analyzed using BioLis24i Clinical Analyzer (Carolina Liquid Chemistries Corp., Winston-Salem, NC, USA) in a reference laboratory. Data was analyzed using SPSS software version 20. Student t-test, One-way ANOVA were done to see the effect of ferritin and TIBC on serum iron. This study received ethical approval from Bangladesh University of Professional and all the ethical issues related the biomedical research were maintained strictly.

\section{Results}

\begin{tabular}{|l|c|}
\hline \multicolumn{1}{|c|}{ Characteristics } & Frequency (\%) \\
\hline Age group & $202(73.7)$ \\
5 to 10 & $72(26.3)$ \\
10 to 14 years & $8.86 \pm 2.035$ years \\
Mean age & \\
\hline Sex of subjects & $137(50.0)$ \\
\hline Male & $137(50.0)$ \\
\hline Female & \\
\hline Class & $79(28.8)$ \\
\hline Class I & $55(20.1)$ \\
\hline Class II & $45(16.4)$ \\
\hline Class III & $49(17.9)$ \\
\hline Class IV & $46(16.8)$ \\
\hline Class V & \\
\hline Family Members & $148(54.0)$ \\
Up to 4 members & $114(41.6)$ \\
5 - 6 members & $12(4.4)$ \\
More than 6 members & $4.55 \pm 1.072$ \\
Mean & \\
\hline Locality & $132(48.2)$ \\
Rural & $142(51.8)$ \\
\hline Urban & \\
\hline
\end{tabular}

Table 1: Socio-demographic distribution of subjects ( $n=274)$.

Among the study participants, male female ratio was equal. The mean age of the study subjects was $8.86 \pm 2.035$ years. Majority of the children were within 5 - 10 years (73.7\%) and rest were within 10 - 14 years. The male and female ratio was equal. Among the participants $28.8 \%$ were in class I, $20.1 \%$ were in class II, and $16.4 \%$ were in class III, $17.9 \%$ in class IV and rest $16.8 \%$ were in class V. Around $48 \%$ study participants were of rural areas.

Among the mothers of the subjects, $76.3 \%$ were housewife while rest were found engaged with individual profession. Among the fathers $26.3 \%$ were service holder, $16.8 \%$ were engaged with business and rest were found engaged in different profession. The education level of the mothers was found as $16.4 \%$ had no institutional education, $44.9 \%$ had primary level, $31.4 \%$ had secondary level (up to SSC), $4.7 \%$ had up to HSC level and $2.6 \%$ were graduate. That of father was found as $14.2 \%$ had no institutional education, $38.0 \%$ had primary level, $37.6 \%$ had secondary level (up to SSC), $5.5 \%$ had up to HSC level and $4.7 \%$ were graduate. 


\begin{tabular}{|c|c|c|}
\hline Characteristics & Frequency & Percent \\
\hline \multicolumn{3}{|l|}{ Mother's Occupation } \\
\hline Housewife & 209 & 76.3 \\
\hline Job Holder & 24 & 8.8 \\
\hline Garments Worker & 14 & 5.1 \\
\hline Other & 27 & 9.9 \\
\hline \multicolumn{3}{|l|}{ Father's Occupation } \\
\hline Service holder & 72 & 26.3 \\
\hline Business & 46 & 16.8 \\
\hline Driver & 36 & 13.1 \\
\hline Cleaner & 28 & 10.2 \\
\hline Day labor & 23 & 8.4 \\
\hline Other & 69 & 25.3 \\
\hline \multicolumn{3}{|l|}{ Mother's Education } \\
\hline No education & 45 & 16.4 \\
\hline Primary level & 123 & 44.9 \\
\hline Secondary level (up to SSC) & 86 & 31.4 \\
\hline Up to HSC & 13 & 4.7 \\
\hline Graduate & 7 & 2.6 \\
\hline \multicolumn{3}{|l|}{ Father's Education } \\
\hline No education & 39 & 14.2 \\
\hline Primary level & 104 & 38.0 \\
\hline Secondary level (up to SSC) & 103 & 37.6 \\
\hline Up to HSC & 15 & 5.5 \\
\hline Graduate & 13 & 4.7 \\
\hline
\end{tabular}

The table 5 shows that the mean hemoglobin was $11.606 \pm$ $1.2551 \mathrm{~g} / \mathrm{dl}$ among the subjects who were under age of 10 years and $12.031 \pm 1.3559 \mu \mathrm{g} / \mathrm{dl}$ among the subjects who were over the age of 10 years, the mean serum iron was $10.942 \pm 3.1499 \mu \mathrm{mol} / \mathrm{L}$ among the subjects who were under age of 10 years and $11.360 \pm$ $3.1426 \mu \mathrm{mol} / \mathrm{L}$ among the subjects who were over the age of 10 years, the mean serum Ferritin was $23.484 \pm 17.2363 \mu \mathrm{g} / \mathrm{l}$ among the subjects who were under age of 10 years and $25.355 \pm 17.7307$ $\mu \mathrm{g} / \mathrm{l}$ among the subjects who were over the age of 10 years, the mean serum TIBC was $58.78 \pm 22.990 \mu \mathrm{mol} / \mathrm{L}$ among the subjects who were under age of 10 years and $59.45 \pm 33.491 \mu \mathrm{mol} / \mathrm{L}$ among the subjects who were over the age of 10 years. Serum iron level was estimated which shows that all the subjects had below $50 \mu \mathrm{g} /$ dl. Only mean hemoglobin was found statistically significant difference between the age group of within and above 10 years of subjects $(\mathrm{p}<0.05)$.

The mean hemoglobin was $11.873 \pm 1.2878 \mathrm{~g} / \mathrm{dl}$ among the male subjects and $11.562 \pm 1.2851 \mu \mathrm{g} / \mathrm{dl}$ among the female subjects, the mean serum iron was $11.277 \pm 3.2239 \mu \mathrm{mol} / \mathrm{L}$ among the male subjects and $10.827 \pm 3.0647 \mu \mathrm{mol} / \mathrm{L}$ among the female subjects, the mean serum Ferritin was $26.226 \pm 18.2698 \mu \mathrm{g} / \mathrm{l}$ among the male subjects and $21.725 \pm 16.1426 \mu \mathrm{g} / \mathrm{l}$ among the female subjects, the mean serum TIBC was $58.78 \pm 23.825 \mu \mathrm{mol} / \mathrm{L}$ among the male subjects and $59.13 \pm 28.270 \mu \mathrm{mol} / \mathrm{L}$ among the female subjects. Statistically significant differences of hemoglobin and Ferritin were found between male and female subjects $(\mathrm{p}<0.05)$

Table 2: Distribution of respondents by socio-demographic characteristics.

\begin{tabular}{|c|c|c|c|c|c|}
\hline Variables & Age & Mean \pm SD & $\mathbf{t}$ & Sig. (2-tailed) & Mean Difference \\
\hline \multirow{2}{*}{$\mathrm{Hb}(\mathrm{g} / \mathrm{dL})$} & Up to 10 years & $11.606 \pm 1.2551$ & \multirow{2}{*}{-2.413} & \multirow{2}{*}{0.016} & \multirow{2}{*}{-0.4246} \\
\hline & Over 10 years & $12.031 \pm 1.3559$ & & & \\
\hline \multirow{2}{*}{ Iron $(\mu \mathrm{mol} / \mathrm{L})$} & Up to 10 years & $10.942 \pm 3.1499$ & \multirow{2}{*}{-0.967} & \multirow{2}{*}{0.334} & \multirow{2}{*}{-0.4180} \\
\hline & Over 10 years & $11.360 \pm 3.1426$ & & & \\
\hline \multirow{2}{*}{ Ferritin $(\mu \mathrm{g} / \mathrm{l})$} & Up to 10 years & $23.484 \pm 17.2363$ & \multirow{2}{*}{-0.785} & \multirow{2}{*}{0.433} & \multirow{2}{*}{-1.8717} \\
\hline & Over 10 years & $25.355 \pm 17.7307$ & & & \\
\hline \multirow{2}{*}{ TIBC $(\mu \mathrm{mol} / \mathrm{L})$} & Up to 10 years & $58.78 \pm 22.990$ & \multirow{2}{*}{-0.185} & \multirow{2}{*}{0.854} & \multirow{2}{*}{-0.663} \\
\hline & Over 10 years & $59.45 \pm 33.491$ & & & \\
\hline
\end{tabular}

Table 3: Serum Hemoglobin, Iron, Ferritin, and TIBC status by age group.

\begin{tabular}{|c|c|c|c|c|c|}
\hline Variables & Sex & Mean & $\mathbf{t}$ & Sig. (2-tailed) & Mean Difference \\
\hline \multirow{2}{*}{$\mathrm{Hb}(\mathrm{g} / \mathrm{dL})$} & Male & $11.873 \pm 1.2878$ & \multirow{2}{*}{2.001} & \multirow{2}{*}{0.046} & \multirow{2}{*}{0.3109} \\
\hline & Female & $11.562 \pm 1.2851$ & & & \\
\hline \multirow{2}{*}{ Iron $(\mu \mathrm{mol} / \mathrm{L})$} & Male & $11.277 \pm 3.2239$ & \multirow{2}{*}{1.185} & \multirow{2}{*}{0.237} & \multirow{2}{*}{0.4505} \\
\hline & Female & $10.827 \pm 3.0647$ & & & \\
\hline \multirow{2}{*}{ Ferritin ( $\mu \mathrm{g} / \mathrm{l})$} & Male & $26.226 \pm 18.2698$ & \multirow{2}{*}{2.161} & \multirow{2}{*}{0.032} & \multirow{2}{*}{4.5007} \\
\hline & Female & $21.725 \pm 16.1426$ & & & \\
\hline \multirow{2}{*}{ TIBC $(\mu \mathrm{mol} / \mathrm{L})$} & Male & $58.78 \pm 23.825$ & \multirow{2}{*}{-0.111} & \multirow{2}{*}{0.912} & \multirow{2}{*}{-0.351} \\
\hline & Female & $59.13 \pm 28.270$ & & & \\
\hline
\end{tabular}

Table 4: Serum Hemoglobin, Iron, Ferritin and TIBC status by sex. 


\begin{tabular}{|c|c|c|c|c|c|}
\hline Variable & & Mean & $\mathbf{t}$ & Sig. (2-tailed) & Mean Difference \\
\hline \multirow{2}{*}{$\mathrm{Hb}(\mathrm{g} / \mathrm{dL})$} & Rural & $11.894 \pm 1.5541$ & \multirow{2}{*}{2.157} & \multirow{2}{*}{0.032} & \multirow{2}{*}{0.3404} \\
\hline & Urban & $11.554 \pm .9692$ & & & \\
\hline \multirow{2}{*}{ Iron $(\mu \mathrm{mol} / \mathrm{L})$} & Rural & $12.082 \pm 3.4969$ & \multirow{2}{*}{5.423} & \multirow{2}{*}{0.000} & \multirow{2}{*}{1.9869} \\
\hline & Urban & $10.095 \pm 2.4303$ & & & \\
\hline \multirow{2}{*}{ Ferritin $(\mu \mathrm{g} / \mathrm{l})$} & Rural & $26.570 \pm 18.8714$ & \multirow{2}{*}{2.390} & \multirow{2}{*}{0.018} & \multirow{2}{*}{5.0060} \\
\hline & Urban & $21.564 \pm 15.4952$ & & & \\
\hline \multirow{2}{*}{$\mathrm{TIBC}(\mu \mathrm{mol} / \mathrm{L})$} & Rural & $56.56 \pm 21.554$ & \multirow{2}{*}{-1.471} & \multirow{2}{*}{0.142} & \multirow{2}{*}{-4.632} \\
\hline & Urban & $61.19 \pm 29.603$ & & & \\
\hline
\end{tabular}

Table 5: Serum Hemoglobin, Iron, Ferritin, and TIBC status by area of residence.

The mean hemoglobin was $11.894 \pm 1.5541 \mathrm{~g} / \mathrm{dl}$ among the rural subjects and $11.554 \pm .9692 \mu \mathrm{g} / \mathrm{dl}$ among the urban subjects, the mean serum iron was $12.082 \pm 3.4969 \mu \mathrm{mol} / \mathrm{L}$ among the rural subjects and $10.095 \pm 2.4303 \mu \mathrm{mol} / \mathrm{L}$ among the urban subjects, the mean serum Ferritin was $26.570 \pm 18.8714 \mu \mathrm{g} / \mathrm{l}$ among the ru- ral subjects and $21.564 \pm 15.4952 \mu \mathrm{g} / \mathrm{l}$ among the urban subjects, the mean serum TIBC was $56.56 \pm 21.554 \mu \mathrm{mol} / \mathrm{L}$ among the rural subjects and $61.19 \pm 29.603 \mu \mathrm{mol} / \mathrm{L}$ among the urban subjects. Statistically significant differences of hemoglobin, iron, and Ferritin were found between rural and urban subjects $(\mathrm{p}<0.05)$.

\begin{tabular}{|c|c|c|c|c|c|}
\hline \multirow[t]{2}{*}{ Model } & Unstandardized Coefficients & Standardized Coefficients & \multirow[t]{2}{*}{$\mathbf{t}$} & \multirow[t]{2}{*}{$\mathbf{F}$} & \multirow[t]{2}{*}{ p-value } \\
\hline & \multicolumn{2}{|c|}{ B } & & & \\
\hline (Constant) & 10.181 & & 21.682 & \multirow[t]{3}{*}{168.810} & 0.000 \\
\hline Ferritin $(\mu \mathrm{g} / \mathrm{l})$ & 0.109 & 0.600 & 13.139 & & 0.000 \\
\hline TIBC $(\mu \mathrm{mol} / \mathrm{L})$ & -0.029 & -0.244 & -5.352 & & 0.000 \\
\hline
\end{tabular}

Table 6: Relationship between serum iron on Ferritin and TIBC.

Statistically we can say that, 1-point increase of the serum Ferritin corresponds to 0.11 points increase of serum Iron. Again 1-point decrease of the serum TIBC corresponds to 0.03 points increase of serum Iron. Serum Iron and serum Ferritin (b coefficients) are positive numbers except TIBC; higher Ferritin is associated with higher iron $(\mathrm{p}<0.05)$.

\section{Discussion}

The present study was conducted among the primary school students of rural and urban settings in Bangladesh and included a total 274 children (132 rural and 142 urban children with equal sexes). The mean age of the respondents was around nine years whereas, majority (74\%) of them were in the age group of 5 to 10 years. Among the mothers of the children, seventy six percent were housewife while rest were found engaged with other profession. Among the fathers more than one-fourth were service holder, and rest were found engaged in other profession including business. The education level of the mothers, around sixteen percent were illiterate, whereas, rest of them were literate. Besides that, among the father, fourteen percent were illiterate, whereas, rest of them were literate.
All the study subjects had Serum iron level below $50 \mu \mathrm{g} / \mathrm{dl}$. This study tried to explore any mean differences of hemoglobin, serum iron, serum ferritin and TIBC among the subjects by age group, gender and by residence. Only mean hemoglobin was found statistically significant difference between the age group of within and above 10 years of subjects, significant differences of hemoglobin and Ferritin were found between male and female subjects and significant differences of hemoglobin, iron, and Ferritin were found between rural and urban subjects $(\mathrm{p}<0.05)$. On One-way ANOVA, it was found that higher Ferritin is associated with higher iron and TIBC was negatively correspond with serum iron, which where are statistically significant $(\mathrm{p}<0.05)$. Similar findings were reported from the studies conducted among university students in Hodeida Province, Yemen [9] and among rural women of reproductive age in Ethiopia [10].

\section{Conclusion and Recommendation}

Prevalence of anemia and insufficiency serum iron among the school going children is marked. Serum Ferritin and TIBC were found having significantly associated with serum iron deficiency. Instead of recommending only iron rich food as counter measure for anemia, plant-based foods containing non-heme iron but building ferritin levels may also suggested for Bangladeshi children. 


\section{Bibliography}

1. Koperdanova M and Cullis J0. "Interpreting raised serum ferritin levels”. BMJ 351 (2015): h3692.

2. Ponka P. "Tissue-specific regulation of iron metabolism and heme synthesis: distinct control mechanisms in erythroid cells". Blood 89.1 (1997): 1-25.

3. Gottschalk R., et al. "Total iron-binding capacity and serum transferrin determination under the influence of several clinical conditions". Clinica Chimica Acta 293 (2000): 127-138.

4. Hamedani P., et al. "Iron depletion and anaemia: prevalence, consequences, diagnostic and therapeutic implications in a developing Pakistani population". Current Medical Research and Opinion 10.7 (1987): 480-485.

5. Heilmann E. "The levels of serum iron and total iron-binding capacity in various diseases". Medizinische Welt 26.37 (1975): 1629-1630.

6. Haseena S., et al. "Study of Serum Iron, Tibc and Serum Ferritin Levels in Rural Women Suffering From Iron Deficiency Anemia". International Journal of Scientific and Engineering Research 5 (2014).

7. Transferrin and Iron-binding Capacity.

8. WHO/CDC. Assessing the iron status of populations. Second edition. WHO/CDC. (2007).

9. Al-alimi AA., et al. "Prevalence of Iron Deficiency Anemia among University Students in Hodeida Province, Yemen". Anemia (2018): 4157876.

10. Gebreegziabher T and Stoecker BJ. "Iron deficiency was not the major cause of anemia in rural women of reproductive age in Sidamazone, southern Ethiopia: A cross-sectional study". PLOS ONE 12.9 (2017): e0184742.

\section{Assets from publication with us}

- Prompt Acknowledgement after receiving the article

- Thorough Double blinded peer review

- Rapid Publication

- Issue of Publication Certificate

- High visibility of your Published work

Website: https://www.actascientific.com/

Submit Article: https://www.actascientific.com/submission.php Email us: editor@actascientific.com

Contact us: +919182824667

Citation: Swapan Kumar Chowdhury., et al. "Iron Deficiency, Ferritin and Total Iron Binding Capacity Among Bangladeshi Children: Urban and Rural Settings". Acta Scientific Nutritional Health 4.2 (2020): 156-160. 